\title{
Local Authority Empowerment towards Quality Living Environment for Coastal Reclamation Area
}

\author{
Mohammad Yusup ${ }^{1,}$, Nor Syafa'ah Ishak ${ }^{2}$, Ahmad Fuzi Arshad ${ }^{3}$ and Yusfida Ayu Abdullah ${ }^{4}$ \\ ${ }^{1,384}$ Centre of Studies of Town and Regional Planning, Faculty of Architecture, Planning and Surveying, 40450 UiTM Shah Alam, Selangor, \\ Malaysia \\ ${ }^{2}$ Centre of Postgraduate Studies of Town and Regional Planning, Faculty of Architecture, Planning and Surveying, 40450 UiTM Shah Alam, \\ Selangor, Malaysia
}

\begin{abstract}
Good urban governance administration system is the key to a successful physical planning development. A local authority of a local government concentrates on planning administration and executes the policies and strategies either the federal or state, or even the local's policies and strategies. Based on its characteristic as the lowest level of government, it becomes the best authority to regulate and monitor the development process within their territory. The significance of a local authority in providing quality living environment invites various academia and professionals to ponder the best urban governance system at a local level. However, there are issues with regards to financial and technical capacity of a local authority, its legal limitation and development instrument adopted in providing urban services for coastal reclamation area in Malaysia. The aim of this paper is to investigate the capability of local authorities in Malaysia in implementing their function as drawn by the legislation. Hence, this paper examines the roles and functions of a local authority as the lowest level of government administration agency in providing urban services; collecting revenue; safeguarding the physical environment in Malaysia, particularly when dealing with development in a coastal reclamation area. Primary data collection was gathered through face-to-face interview sessions involving government agencies and stakeholders. Legal documents, policies and development plans were then analysed to support the primary data for further understanding of the issues concerning the capacity of a local authority especially when providing urban services within its area. The study is expected to provide a new approach to local authorities in Malaysia in providing quality living environment in terms of development procedure, the role and function, legal empowerment, and decentralisation of function particularly in enhancing the current practices at local level.
\end{abstract}

\section{Introduction}

Malaysia is a small country that covers $330,290 \mathrm{~km}^{2}$ of a total land area including Sabah and Sarawak [1]. West Malaysia and East Malaysia are separated by the South China Sea. Malaysia is located in South East Asia and consists of 14 states; 11 states in West Malaysia, the States of Sabah and Sarawak as well as the Federal Territory of Kuala Lumpur (the capital city of Malaysia) [2]. The planning system in Malaysia has been developed based on the Federal Constitution in which matters related to town planning are stated in the Ninth Schedule under List III of the Concurrent Lists [3]. Federal government, state government and local authority has the responsibility towards the activities related to town planning in order to maintain, monitor and specify the use of land and buildings, so that the planning are better organised especially in meeting the need of the public interests [4]. However, the planning system in Malaysia can be changed according to the demand and need as well as the technological advances. The process of town planning in Malaysia had started from Malay Sultanate era, expended by the British colonialists, and had undergone various changes after the independence of Malaysia in 1957 until the introduction of the Town and Country Planning Act 1976 (Act 172). These changes were aimed to create a happy quality living environment in line with the increasing socio-economic condition of the people and country. The town planning's main objective which is to protect the public interest had not changed, but the scope and nature of town planning have greatly expanded from time to time. Hence, a practical organisational and administrative structure plays an important role in ensuring the consistency of the physical planning and the organisation resilient.

The limitation of this paper is that it only focuses on the local authority's empowerment in implementing the roles and function provided by the statutory and nonstatutory instruments in providing urban services. The expected outcome of this study is to provide a new approach to local authorities in Malaysia in providing a good quality living environment in terms of development procedure, role and function, legal empowerment as well

\footnotetext{
a Corresponding author: mohammad1744@salam.uitm.edu.my
} 
as new guidance in sustaining the financial expenditure decentralisation of function for local authorities.

\section{Research methodology}

This paper focuses on the local authority empowerment towards a quality living environment for coastal reclamation area. This study applies a case study design and a qualitative approach as it outlines all the problems experienced by the local authority before recommendation and proposals be made to overcome the issues. A case study approach is seen fitting since it is "a process that is carried out in order to solve the past and current problems as well as doing a continuous study for future improvements" [5]. The study therefore, attempts to enhance the development procedure, role and function, legal empowerment and decentralisation of a local authority's power in Malaysia. Furthermore, the paper is intended to study the capability of local authorities in Malaysia in implementing their function as drawn by the Malaysian law. Primary data collection is gathered through face-to-face interview sessions with government agencies and stakeholders. Purposive sampling was chosen to get feedbacks from the respondents through interview sessions which were conducted with the selected informants. Legal documents, policies and development plans were then analysed to support the primary data to further understand the issues about the capacity of a local authority when providing urban services within its local context.

\section{Literature review}

The process of development apparently comes after performing proper physical planning. This is because planning is the process in deciding what and how to carry out development and this happens at many levels such as from day to day decision by individuals or families, also in making a complex decision by businesses and governments [6]. However, planning, in linguistic, is the act or the process of making a plan which comes from the word 'plan' and it can be interpreted as to make detailed arrangement for the future [7]. According to Keeble (1969) [8], planning is the art and science of ordering the use of land and siting of building and communication routes so as to secure the maximum practicable degree of economy, convenience and beauty. While, Ratcliffe (1974) [9] defines planning differently from Keeble (1969) [8] and believed that planning is providing the right site, at the right time, in the right place and for the right people. Interestingly, the definition of planning from Ratcliffe [9] perspective tends to define planning as a service provider while Keeble (1969) [8] described planning as an action to create a better environment and living place. There is significant similarity of both definitions where it has the element of decision making. The action of ordering the use of land and siting of a building and providing the right site at the right time for the right people as Ratcliffe (1974) [9] had stated requires a decision-making process. The element of decisionmaking process is undoubtedly the basic principle shared by both definitions. Thus, it can be concluded that planning is actually the process of decision making where it requires goal, target group and proper procedures [10].

\subsection{Administration systems in West Malaysia}

The West Malaysia consists of a three-level administrative system which are the Federal Government, State Government and Local Authority [11] (Figure 1).

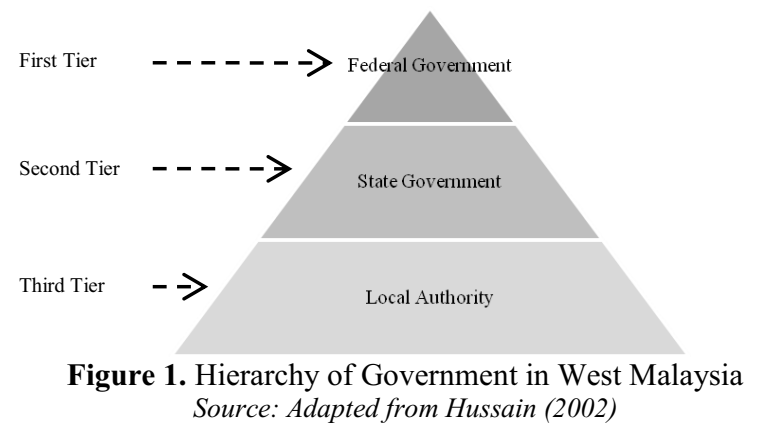

There will be no perfect system that can run smoothly for government's activities. This causes the multiple department and units under one country to be approached. Decentralisation commonly known as the transfer of powers of state or national responsibilities or functions from central government to the sub-national level of government, or from central agencies or offices to regional bodies or branch offices, or to nongovernmental organisation or private concerns [12]. On the other hand, Miller (2002) [12] concluded decentralisation as the redefinition of structures, procedures and practices of governance to be closer to the citizenry. Decentralisation also can be defined as a dynamic process, in which actors at every level of government can interact and find the appropriate balance among the responsibility of the authorities in their scope of work (Barr, Resusodarmo, Dermawan, McCarthy, Moeliono and Setiono, 2006) [13].

According to Hutchcroft (2001) [14], the decentralisation involves as much more extensive transfer of decision-making authority and responsibility to the local government units and it is usually involving regions, provinces, and/or municipalities. Hence, this concept of work can be seen as a sharing-power concept. The advantages of this system are more flexible and provide faster decision-making process, encouraging the public participation in the decision-making process as well as develop democracy concept. This sharing-power concept is easy to control, implemented and gaining public (local people) approval and minimising the arising problems [15]. Although, the weakness of decentralisation are the corruption, the local authorities still rely on the higher government decisions, inefficiency when other local authorities cannot command as the administrator and local authority do not have sufficient resources to provide adequate services to the people because of the local authority position is small compare to the higher government [15].

Furthermore, there are three types of decentralisation of power for instance de-concentration, devolution and 
delegation. De-concentration can be defined as the process involving the redistribution of administrative responsibility among federal government only [16]. While, the World Bank (1999) [17] stressed that deconcentration is the weakest form of the decentralisation of power. It is due to the redistribution of decision making authority and financial responsibilities among different levels of the national government [17]. This is the process where the federal or state government representing their authority or power to the staff in the local authority unit [16]. For example, in West Malaysia, the Ministry of Urban Wellbeing, Housing and Local Government (MUWHLG) will have other departments in every state with the intention of serving the people.

Apart from that, devolution is the devolution of decision making power in certain areas or regions passed to the local authorities or local government bodies of the area [11]. The local authorities' administration act as devolution and the district administration act as a deconcentration [11]. The devolution happens where the transfer of any function or responsibility involving both administrative as well as political or decision makers [12]. There are four characteristics of devolution in planning administration structure which are i) distinct geographical boundary for local planning authority to perform their responsibility, ii) the federal government control towards local planning authorities is limited and indirect, as autonomous, free and separated from the federal government, iii) the power to collect financial resources to perform duty, known as financial autonomy and iv) the devolution is a form that requires the local authority to be established as an institution [10]. Thus, Table 1 will explain the differences between deconcentration and devolution and the definitions of the delegation of powers will be explained below.

Table 1. Differences between De-concentration and Devolution

\begin{tabular}{|l|l|l|}
\hline \multicolumn{1}{|c|}{ Aspect } & \multicolumn{1}{|c|}{ De-concentration } & \multicolumn{1}{c|}{ Devolution } \\
\hline $\begin{array}{l}\text { Administration } \\
\text { Order }\end{array}$ & $\begin{array}{l}\text { Administration is } \\
\text { through administration } \\
\text { order. }\end{array}$ & $\begin{array}{l}\text { Administration is } \\
\text { through act of law. }\end{array}$ \\
\hline $\begin{array}{l}\text { Efficiency of } \\
\text { the }\end{array}$ & $\begin{array}{l}\text { The administration lacks } \\
\text { of efficiency because it } \\
\text { is depends on the } \\
\text { discretion of officers. }\end{array}$ & $\begin{array}{l}\text { The administration is } \\
\text { efficiently works } \\
\text { because it is directly } \\
\text { close to state. }\end{array}$ \\
\hline $\begin{array}{l}\text { Flexibility of } \\
\text { the }\end{array}$ & $\begin{array}{l}\text { The flexibility in the } \\
\text { administration is less } \\
\text { rigid and more flexible } \\
\text { because the orders serve } \\
\text { as guidelines. }\end{array}$ & $\begin{array}{l}\text { The flexibility in } \\
\text { administration can be } \\
\text { rigid because the } \\
\text { provisions stated in } \\
\text { the laws need to be } \\
\text { adhered. }\end{array}$ \\
\hline $\begin{array}{l}\text { Creativity and } \\
\text { Originality }\end{array}$ & $\begin{array}{l}\text { Encouraging creativity } \\
\text { and originality in the } \\
\text { administration }\end{array}$ & $\begin{array}{l}\text { Creating the creativity } \\
\text { and originality in the } \\
\text { administration }\end{array}$ \\
\hline Management & $\begin{array}{l}\text { Have more proves of } \\
\text { abuse of power, position } \\
\text { and corruptions. }\end{array}$ & $\begin{array}{l}\text { Faced less abuse of } \\
\text { power, position and } \\
\text { money. }\end{array}$ \\
\hline $\begin{array}{l}\text { Legitimate } \\
\text { Power }\end{array}$ & $\begin{array}{l}\text { Questioned arising on } \\
\text { legality legitimacy. }\end{array}$ & $\begin{array}{l}\text { Act carried out are } \\
\text { legal and legitimate. }\end{array}$ \\
\hline
\end{tabular}

Table 1 demonstrates that the decision made by applying the concept of de-concentration is not good as the decentralisation concept. Excluding the local interest regarding the local matter jeopardises the decision making process. Apparently, de-concentration is not recommended especially for a particular state with large geographical boundary as local views are important. On the contrary, devolution of power enables the local planning authority or state planning authority performing their duty and it can indirectly improve the public participation in planning matters [10]. By doing this, the problem related to 'inertia', 'apathy' as well as dependency to the federal government on the local matter can be avoided and it also will indirectly improve the sense of belonging among the people towards the government [11].

The delegation of powers is the term used when the transfer of function from governments to a nongovernmental organization or private sector entity (privatisation) [12]. Ferguson and Chandrasekharan (2004) [18] defined delegation as the transfer of managerial responsibility for specified functions to other public organisation outside normal federal government control, whether district or local government or stateowned agencies. As an example, this scenario can be seen in the coastal reclamation development in Melaka. The coastal reclamation is being introduced in order to provide more land due to the limited land resources [19]. Besides, coastal reclamation is a way that helps in creating a new land from the ocean into a form that benefits and meets the public interests [20]. Apart from that, coastal reclamation provides an opportunity to expand the land for human use through a variety of purposes [21]. The development of the coastal area for reclamation purposes should take an important measure in evaluating any possible disturbances in the development of coastal area because the coastal area is a very sensitive area [19].

The land is under the state government power, but the government privatizes the project to the developer to develop the reclamation area in order to provide the need of the people that the state government and local authority could not provide. In Melaka, most of its coastal reclamation area is used to provide residential, commercial and mix development [22]. This action is made in order to meet the demand for development and reduce population pressure especially in a small state like Melaka. This shows that coastal reclamation is vital towards economic viability and has potential in increasing the quality living environment.

With an increasing number of populations, inevitably it will slowly cause problems to the federal and state government relating to the public facilities and infrastructures inadequacy because those are the basic needs of people especially in an urban area and historical tourism place like Melaka [23]. Hence, coastal reclamation development can lighten the burden by having a lot of public facilities and infrastructures to be built on the said area. This explains that reclamation is important in boosting the economy; meet the social needs and helping the environment towards the quality living environment. Still, the delegation of powers needs to be monitored so that the developer does not freely develop the land as they desired, therefore, avoiding conflict of land use and the demand from people. Even though the project is privatized, the quality of the development needs to be put at the top priority. 
As another example, the delegation of power in housing development scheme is now facing issues especially for the developers to develop low-cost housing. Developers tend to develop medium cost to high-cost housing scheme with a high price which is profitable to them that resulted in issues of owning properties for the lower income group [24]. The development on reclaimed land as well encounter the same problems where the developer only focuses on the high cost development that is profitable such as the development of Hatten City and Cheng Ho City and other upcoming developments [25].

\section{Results and discussion}

\subsection{Local authority in Malaysia}

Local authority plays an imperative role to facilitate the economic activities and development of a region especially in delivering public goods and services that are particular to the localities [26]. The local authority has the power to control all physical development activities within its area [4]. Section 5(1) of the Town and Country Planning Act 1976 (Act 172) clearly stated that every Local Authority shall be the Local Planning Authority for the area of the Local Authority. The local authority in West Malaysia is therefore governed by the Local Government Act 1976 (Act 171). However, the East Malaysia which consists of the states of Sabah and Sarawak, apply their own ordinances to govern over their territory [3]. For that reason, Sabah is governed by the Local Government Ordinance 1961 and Sarawak is governed by the Local Authority Ordinance 1966.

This paper only focuses on the Act 171 as it is only applied in West Malaysia. The local authorities were established under the Local Government Act 1976 (Act 171) and the respective state ordinances and by-laws [27]. Local Authority means any City Council, Municipal Council or District Council, as the case may be, and in relation to the Federal Territory means the Commissioner of the City of Kuala Lumpur appointed under Section 4 of the Federal Capital Act 1960 (Act 190) as stated in the Local Government Act 1976 (Act 171). Local government act as a system of a district, a territorial unit that have their own boundary and territory, legal entity, instructional structure, have the power to govern the area and task to fulfill, which is subject to particular acts, has a financial authority and other autonomy [28]. The local authority is the third tier in the government system in Malaysia.

The local authority is created in order to be a step closer to the people so that the voices, demands and needs from the people can be heard by the government [29]. Moreover, a local authority is responsible in making a local plan for their area as stated in Section 12 (Act 172). The purpose of a local plan covers the policies, proposal designed in order to achieve planning aims in development for the area and structure plan strategies for development application [30]. Besides, a local plan is an essential development plan for the working planning system, also the quality of the produced local plan plays an important factor in determining the capability of the local plan to be a success or failure of the development [30]. Indiscriminate of activities for land development and poorly planned of built environment leads to environmental degradation, hence giving impact to public health [31]. This demonstrates that a comprehensive good current and future physical planning development gives various positive impacts physically, socially, economically and environmental pleasure.

Malaysia consists of 149 local authorities including the Sabah, Sarawak and Wilayah Persekutuan [32]. This indicates that Malaysia has a huge number of local authorities. The categories of local authorities are divided into three types which are city hall/municipal council, city council and district council [33]. The three types of local authorities have their own range of responsibility that reflects on their size and capacity. Local authority are formed and regulated by the respective state's legislation and subordinate to the respective state governments [26]. Table 2 shows the list and categories of the local authorities in Malaysia.

Table 2. Lists and Categories of Local Authority in Malaysia

\begin{tabular}{|c|c|c|c|c|c|}
\hline No. & State & $\begin{array}{l}\text { City } \\
\text { Hall/Municipal } \\
\text { Council }\end{array}$ & $\begin{array}{r}\text { City } \\
\text { Council }\end{array}$ & $\begin{array}{l}\text { District } \\
\text { Council }\end{array}$ & Total \\
\hline 1. & Johor & 1 & 6 & 8 & 15 \\
\hline 2. & Kedah & 1 & 3 & 7 & 11 \\
\hline 3. & Kelantan & 0 & 1 & 11 & 12 \\
\hline 4. & Melaka & 1 & 3 & 0 & 4 \\
\hline 5. & $\begin{array}{l}\text { Negeri } \\
\text { Sembilan }\end{array}$ & 0 & 3 & 5 & 8 \\
\hline 6. & Pahang & 0 & 3 & 8 & 11 \\
\hline 7. & $\begin{array}{l}\text { Pulau } \\
\text { Pinang }\end{array}$ & 1 & 1 & 0 & 2 \\
\hline 8. & Perak & 1 & 4 & 10 & 15 \\
\hline 9. & Perlis & 0 & 1 & 0 & 1 \\
\hline 10. & Selangor & 2 & 6 & 4 & 12 \\
\hline 11. & Terengganu & 1 & 2 & 4 & 7 \\
\hline 12. & Sabah & 1 & 2 & 21 & 24 \\
\hline 13. & Sarawak & 3 & 3 & 20 & 26 \\
\hline 14. & $\begin{array}{l}\text { Federal } \\
\text { Territory }\end{array}$ & 1 & 0 & 0 & 1 \\
\hline & Total & 13 & 38 & 98 & 149 \\
\hline
\end{tabular}

Meanwhile, local authorities have their own functions and responsibilities. There are four main functions of local authority as highlighted in the Local Government Act 1976 (Act 171); environment, social, public and security (Figure 2).

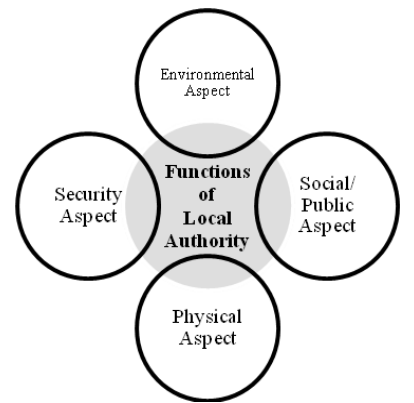

Figure 2. The Functions of Local Authority in Malaysia Source: Adapted from Local Government Act 1976 (Act 171; Section 74-84) 
The four functions stated above are interlinked with each other; i) having a good surrounding environment helps to harmonize the area of development especially in the residential area. The environment element focuses on road services, traffic control especially in the town or city at peak hours, lamp post, recreation park that people can take time to get rest with a nice environment and surrounding, provide a proper drainage and culvert system, flash flood control and other related services, ii) local authority usually in-charge of the cleanliness activities for instance garbage collection (in residential, commercial, industrial, recreation area, and open spaces), sewerage, sanitation and others. Besides, local authority also provides education and health facilities. Apart from that, local authority has initiatives in protecting the handicap such as building shelter, welfare house for old folks, housing as well as creating cultural activities, iii) physical aspects which focus on bus stand, parking area, town hall, fields, community halls or sports centre in exchange for planning permission and council services. The provision of these public services becomes the asset to the council, where the fees and charges are collected for the use of facilities provided, and lastly, iv) highsecurity area is vital in ensuring people to be safe and secured all the times. Thus, the security elements are focused on the public facilities such as police station, fire station, taking action on public nuisance and others. Above all, the function of a local authority as mentioned by the Act 171 possesses a close relationship between local authority and the local communities.

\subsection{Issues and problems of local authority in providing urban services}

An interview session was conducted with the responsible officer in Johor Bahru City Council, Melaka Historical City Council and Pulau Pinang City Council which revealed various problems experienced by the local authority in providing urban services includes; i) the capability of local authority in managing their territory, ii) development instrument adopted by local authority in promoting quality living environment, iii) limitation of the local authority in interpreting the law to generate revenue, and, iv) limitation in enforcement of laws. These three local authorities were preferred because of their involvement in coastal reclamation development within their area [34-36].

It is very important for the local authority to be given the definite and full authority or power in carrying out duty to ensure the effectiveness of its function and indirectly ease the decision making process [10]. The income and resources of the local authority must be suitable with its duty and function, so that it can deliver the job within its own institution based on their capability as the responsible authority in managing the local matter [10]. Based on Act 171, the local authority acquires revenue through general tax revenues and fines [37]. Part $\mathrm{V}$ of Local Government Act 1976 (Act 171), provides the financial sources of the local authorities in West Malaysia [37]. Section 39 of Local Government Act 1976 (Act 171) explains the revenue of a local authority shall consist of; (a) all taxes, rates, rents, license fees, dues and other sums or charges payable to the local authority by virtue of the provisions of this Act or any other written laws; (b) all charges or profits arising from any trade, service or undertaking carried on by the local authority under the powers vested in it; (c) all interest on any money invested by the local authority and all income arising from or out of the property of the local authority, movable and immovable; and (d) all other revenue accruing to the local authority from the Government of the Federation or of any State or from any statutory body, other local authority or from any other sources as grants, contributions, endowments or otherwise. The provision on Section 39 of the Local Government Act 1976 (Act 171 ) is the basis for every local authority in West Malaysia to generate revenue [11]. According to the Commonwealth Local Government Forum (2013) [38], the local authority's income mainly from the three sources, which are taxes, non-tax revenue and allocations from the federal and state government.

Besides, the local authority also obtained financial resources from grants and advances from the state or federal government as well as from loans that have been granted [11]. This is due to the increase in the cost of expenses like building materials and others. The lack of financial provisions can lead to some projects to be postponed or cancelled [11]. Interview sessions with the responsible officers in Johor Bahru City Council, Melaka Historical City Council and Pulau Pinang City Council revealed that the fund generated by the local authority is insufficient and additional allocation is required from the state or federal government. In practice, the state government is required to provide an additional fund to almost all local authority within the state for various purposes including the provision of urban services. Additionally, for the Melaka Historical City Council, where massive coastal reclamation development is being carried out, the difficulties of providing the urban services is due to the incomprehensive of the planning guideline in development for coastal reclamation [23]. The lacks of detail in planning guideline directly affect the financial and physical planning of the urban services. Nevertheless, some recommendation has been outlined by the local authorities urging for the implementation of the Safe City concepts through the nation [39]. The safe city is being introduced for people to live peacefully without being worried of their surrounding environment. The element in a safe city such as the pedestrian walkway, motorcycle lock area, safety mirror, CCTV and others help in promoting the quality living environment. Each local authority has their own way in managing their area. By promoting Safe City concept, additional financial budget and taxes from the urban services can be increased [39]. However, as the third tier in the structure of the administration system, local authorities are facing several problems in relation to the intervention of power within the federal government and state government at local level. The intervention of power will always hinder the process of developing the urban services. The financial funding for the local authority must be allocated sufficiently so that local authority can execute their duty 
and offer great services to the people [10]. The local authority should stand on their own feet without any interference from the upper-level governments.

\section{Key findings}

After several interview sessions with some responsible officers in the local authorities and further understanding the characteristic of the local authority, the study had therefore identified several important findings that can suggest a few relevant recommendations in improving and enhancing the local authority empowerment towards a more quality living environment for coastal reclamation area.

- The planning administration system in West Malaysia needs to have a structured approach to improvement and clear practices of the roles and responsibilities for each level of government. This is because the intervention from the upper-level in administrative matters can result as the conflict of roles and responsibilities between the governments. Thus, this matter contributes to the inefficiency and incompetence at a local level. The intervention from the upper level of government usually caused by political decision creating difficulties in planning and providing the urban services as financial allocation could be biased and not according to the needs of the people. The political intervention also hinders the enforcement action taken by the local authority to generate additional revenue.

- Limitation in the human resources of the local authority is also one of the factors that hinder the process of providing quality urban services by the local authority. The limitation in man-power and lack of expertise/knowledgeable officer in local authority had caused difficulties in enforcing the law when the enforcement is supposed to be one of the sources for the local authority for income generation.

- The lack of understanding of the law reduces the capacity of a local authority to explore an additional area to increase the financial fund to provide urban services in their territorial area. Part V of Local Government Act 1976 (Act 171) is not properly utilised by the local authority especially in terms of investment, mortgages or debenture stock.

- Incomprehensiveness of the development control instrument, especially in coastal reclamation area, hinders the process of financial and physical planning of the urban services. The current instrument used by the local authority is incapable in guiding the local authority to outline a systematic planning of the urban services. The development instrument includes the planning guideline and the development plan system adopted by the local authority.

\section{Conclusions}

Empowerment of the local authority particularly on the human resources, independency of local government and development control instrument should be able to overcome the existing problems with regard to the provision of quality urban services in the coastal reclamation area. However, intervention by upper-level government and the political decision must be avoided so that the decision made by the local authority can be materialized. Nevertheless, the monitoring process is also essential in ensuring that the financial allocation is well spent by the local authority. Further understanding the laws and regulations by the local authority will help the local authority to explore an alternative area for local government to generate additional revenue in order to reduce the dependency of the local government to the federal and state government. Good physical planning comes with good urban planning governance. For that reason, the local authority should initiate a paradigm shift in governing their territorial area in trying to provide quality urban service in land reclamation area.

\section{Acknowledgement}

The author would like to thank the Ministry of Higher Education Malaysia for funding this research under the Research Acculturation Grant Scheme (Grant 600RMI/RAGS 5/3 (135/2014)), and the Universiti Teknologi MARA (UiTM), as well as the Research Management Centre (RMC) UiTM for the management and support of this research.

\section{References}

1. Department of Statistics. Yearbook of Statistics Malaysia, 2010. Department of Statistics, Malaysia. (2011).

2. A. J. Yunus. Country Profiles: Malaysia. Malaysia: United Cities and Local Government (UCLG). (2005).

3. The Commissioner of Law Revision. Federal Constitution. Selangor: International Law Book Services. (2014a).

4. The Commissioner of Law Revision. Town and Country Planning Act 1976 (Act 172). Selangor: International Law Book Services. (2014b).

5. M. Hammond and J. Wellington. Research Methods: The Key Concepts. Routledge Key Guides. (2013).

6. T. Litman. Planning Principles and Practices. Victoria Transport Policy Institute. (2013).

7. A. S. Hornby. Oxford Advanced Learner's Dictionary. London: Oxford University Press. (2010).

8. L. Keeble. Principle and Practice of Town and Country Planning. London: Estate Gazette Ltd. (1969).

9. J. Ratcliffe. An Introduction to Town and Regional Planning. London: Hutchinson and Co. Publisher Ltd. (1974).

10. M. Yusup. Statutory Procedure and Planning Machinery for Urban Development in Sarawak. Shah Alam: Universiti Teknologi MARA. (2013).

11. A. A. Hussain. Kerajaan Tempatan: Teori dan Peranan di Malaysia. Kuala Lumpur: Dewan Bahasa dan Pustaka. (2002). 
12. K. L. Miller. Advantages and Disadvantages of Local Government Decentralisation. Carribean Conference on Local Government and Decentralisation, 4. (2002).

13. C. Barr, I. A. P. Resosudarmo, A. Dermawan, J. McCarthy, M. Moeliono and B. Setiono. Decentralisation of Forest Administration in Indonesia: Implications for Forest Sustainability, Economic Development and Community Livelihoods. Jakarta: Center for International Forestry Research. (2006).

14. P. D. Hutcheroft. Centralization and Decentralization in Administration and Politics: Assessing Territorial Dimensions of Authority and Power. Governance: An International Journal of Policy and Administration, Vol. 14, No. 1, January. Blackwell Publisher. (2001).

15. H. J. B. Allen. Cultivating The Grass Roots: Why Local Government Matters. All India Institute of Local Self-Government. p.3-10. (1990).

16. A. A. Hussain. Pengantar Pentadbiran Awam. Kuala Lumpur: Utusan Publications and Distributors Sdn. Bhd. (1983).

17. World Bank. Beyond the Center: Decentralising the State. Washington D.C.: World Bank. (1999).

18. I. Ferguson and C. Chandrasekharan. Paths and Pitfalls of Decentralization for Sustainable Forest Management: Experiences of the Asia-Pacific Region. ITTO Tropical Forest Update. (2004).

19. N. M. Nadzir, M. Ibrahim and M. Mansor. Impacts of Coastal Reclamation to the Quality of Life: Tanjung Tokong Community, Penang. AMER International Conference on Quality of Life (p. 10). Kota Kinabalu, Sabah, Malaysia: Procedia Social and Behavioral Sciences. (2014).

20. A. Sufian and M. Mustafa. Emerging Issues on Reclaimed Land in Malaysia: Alienation for Freehold or Leasehold?. International Seminar \& Indonesia Forum on Ocean Law and Resources: Building Comprehensive Perspective on National Security and Sustainable Development. Faculty of Law Brawijaya University (2010).

21. B. Win and V. Choa. Reclamation and Ground Improvement. Thomson Learning. (2004).

22. Melaka Historical City Council. Issues and Problems of Coastal Reclamation in Malacca. Central Malacca: Malacca Historical City Council. (2015).

23. Melaka Town and Country Planning Department. Coastal Land Reclamation in Melaka. Melaka: Melaka Town and Country Planning Department. (2015).

24.Z. A. Hashim. House Price and Affordability in Housing in Malaysia. Bangi: Universiti Kebangsaan Malaysia (UKM). (2010).

25. L. J. Wyn. Melaka Forges Ahead. The Edge Malaysia. Melaka, Malaysia: The Edge Malaysia. (2011, May 9).

26. F. W. Ibrahim. Local Public Goods and Citizen Satisfaction: A Case Study of District of Sik, Kedah, Malaysia. Proceedings of 5th Asia-Pacific Business Research Conference (ISBN: 978-1-922069-44-3) (pp. 1-9). Kuala Lumpur: 5th Asia-Pacific Business Research Conference. (2014).
27. Royal Malaysian Customs Department. Guide on Government, Local Authority and Statutory Body. Royal Malaysian Customs. (2014).

28. D. M. Hill. Democratic Theory and Local Government. London: Allendand Unwin Ltd. (1974).

29. S. Khalil and S. A. Adelabu. Modelling Local Government System in Nigeria. Kuwait Chapter of Arabian Journal of Business and Management Review Vol. 1, No.1; September 2011, 136-154. (2011).

30. S. M. Yusoff, F. Yusof and A. F. Arshad. An Analysis of Local Plan for Development Control at Local Planning Level in the State of Selangor. AcE-Bs 2014 Sabah ASEAN Conference on EnvironmentBehaviour Studies The Pacific Sutera Hotel, Sutera Harbour, Kota Kinabalu, Sabah, Malaysia, 04-05 January 2013 "Quality of Life in the Built and Natural Environment" (pp. 574-584). Selangor: Elsevier Ltd. (2014).

31. A. J. Maidin and N. F. S. Ahamed. Mandatory Health Impact Assessment in Malaysian Land Planning and Development Control System. AicE-Bs 2012 Cairo ASIA Pacific International Conference on Environment-Behaviour Studies Mercure Le Sphinx Cairo Hotel, Giza, Egypt, 31 October 2 November 2012 "Future Communities: Socio-Cultural \& Environmental Challanges", 164. Vol. 68. (2012).

32. Portal One Stop Centre (OSC). Portal One Stop Centre (OSC). Retrieved from Senarai PBT di Malaysia: Pihak Berkuasa Tempatan: www.epbt.gov.my. (2015, 10 10).

33. The Commissioner of Law Revision. Malaysia Kita: Panduan dan Rujukan untuk Peperiksaan Am Kerajaan. Kuala Lumpur: International Law Book Services. (2000).

34. Johor Bahru City Council. Finance. Johor Bahru: Johor Bahru City Council. (2015).

35. Melaka Historical City Council. Finance. Central Malacca: Malacca Historical City Council. (2015).

36. Pulau Pinang City Council. Finance. Pulau Pinang: Pulau Pinang City Council. (2015).

37. The Commissioner of Law Revision. Local Government Act 1976 (Act 171). Selangor: International Law Book Services. (2014c).

38. Commonwealth Local Government Forum (CLGF). The Local Government System in Malaysia. United Kingdom: Commonwealth Local Government Forum (CLGF). www.clgf.org.uk. (2013).

39. Department of Town and Country Planning. Safe City. Selangor: Department of Town and Country Plannings. (2010). 